\title{
MACRO- AND MICROMORPHOLOGY OF FLACOURTIA CATAPHRACTA ROXB CULTIVATED IN EGYPT: STEM, LEAF, AND STEM-BARK
}

\author{
H. M. Sayed ${ }^{1}$, M. H. Mohammed ${ }^{2}$, F. M. M. Darwish ${ }^{1}$ and A. M. Mohammed ${ }^{2}$ \\ ${ }^{1}$ Department of Pharmacognosy, Faculty of Pharmacy, Assiut University, Assiut 71526, Egypt \\ ${ }^{2}$ Department of Pharmacognosy, Faculty of Pharmacy, Al-Azhar University, Assiut 71524, \\ Egypt
}

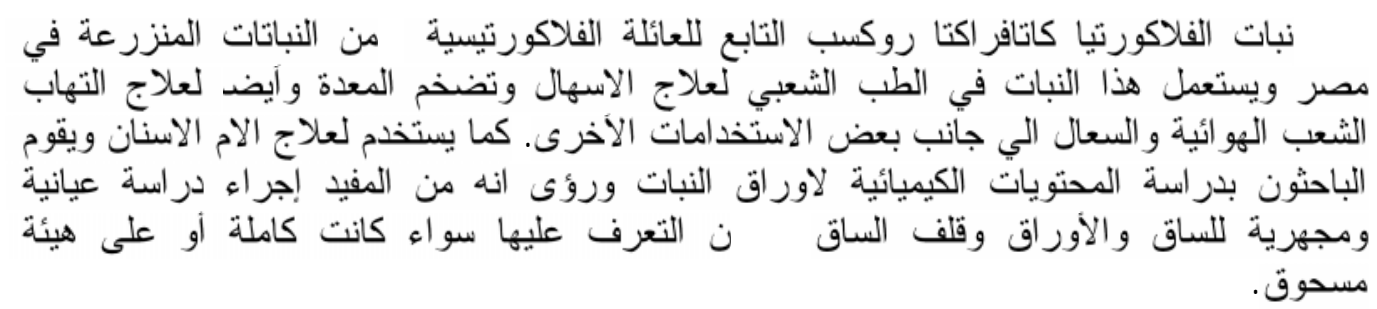

The detailed macro-and micromorphological characters of the stems, leaves and stembark of Flacourtia cataphracta Roxb. (Syn. F. jangomas Raeusch) were studied with the aim to find out the diagnostic elements of these organs, which facilitate their identification in both entire and powdered forms.

\section{INTRODUCTION}

The genus Flacourtia (Family: Flacourtiaceae) comprises about 15 species of tropical and subtropical Asian and African countries. ${ }^{1,2,3}$

Flacourtia cataphracta Roxb (syn. F.jangomas Raeusch) ${ }^{4,5}$ (Fig. 1) is a shrub or erect low-branched tree. This species is native to North Bengal, East Bengal and Chittagong in India, commonly cultivated throughout South East Asia, Eastern Malaya, the Philippines ${ }^{5,6}$ and also in Fiji. ${ }^{1,7}$. It is used in the Indian folk medicine as tonic, diaphoretic, stomachic, in the treatment of diarrhea and distended stomach. The powdered dried leaves are employed to relieve bronchitis and cough. The leaves and bark are applied on bleeding gums and aching teeth. The bark infusion is gargled to alleviate hoarseness. The pulverized roots are poulticed on sores and skin eruption and held in mouth to toothache while the root juice was applied to herpes. The fruits are eaten to overcome biliousness, nausea and diarrhea. ${ }^{4,5,6}$

Flacourtiaceae has not yet been extensively studied. Preliminary phytochemical screening of the title plant revealed the presence of sterols, triterpenes, flavonoids, tannins, saponins and coumarins. Few studies have been carried out on this plant concerning its chemical constituents, where limonoids ${ }^{8}$ and triterpenes $^{9}$ have been identified from it. However, nothing could be traced concerning the macro- and micromorphological characters. This prompted us to undertake a pharmacognostical investigation of this plant. This work describes the macro- and micromorphological characters of the stem, leaves and stem-bark of Flacourtia cataphracta Roxb.

\section{MATERIAL}

The plant material was obtained from the botanical garden at Aswan where it is cultivated and authenticated in the Botanical Garden index. The Plant was collected in May 2001 and was kindly identified by Dr. Hafeez Rafael Habeb (Assistant researcher in the Botanical Garden). Fresh stem, leaves and stem-bark were preserved, separately, in a mixture of $70 \%$ alcohol-glycerin-water $(1: 1: 1)$ 
until used. For the study of the powder, the stem, leaves and stem-bark were air-dried, reduced to powder and kept for microscopical investigation.

\section{Habitat}

Flacourtia cataphracta Roxb (Fig. 1) is a shrub or an erect, low branched tree, 8-10 m high. It has young spiny branches and flaking bark. The leaves are simple alternate or spirally arranged, pale pink where young, oval to lanceolate, toothed, very thin, glossy on both surfaces and reaching 5-10 $\mathrm{cm}$ in length and $1.25-5 \mathrm{~cm}$ in width. The male and female flowers are on separate trees. They are greenish, heavily fragrant, borne in small clusters on new brachlets. The fruits are round or slightly oval reaching $2-2.5 \mathrm{~cm}$ in diameter and dark-marron in colour.

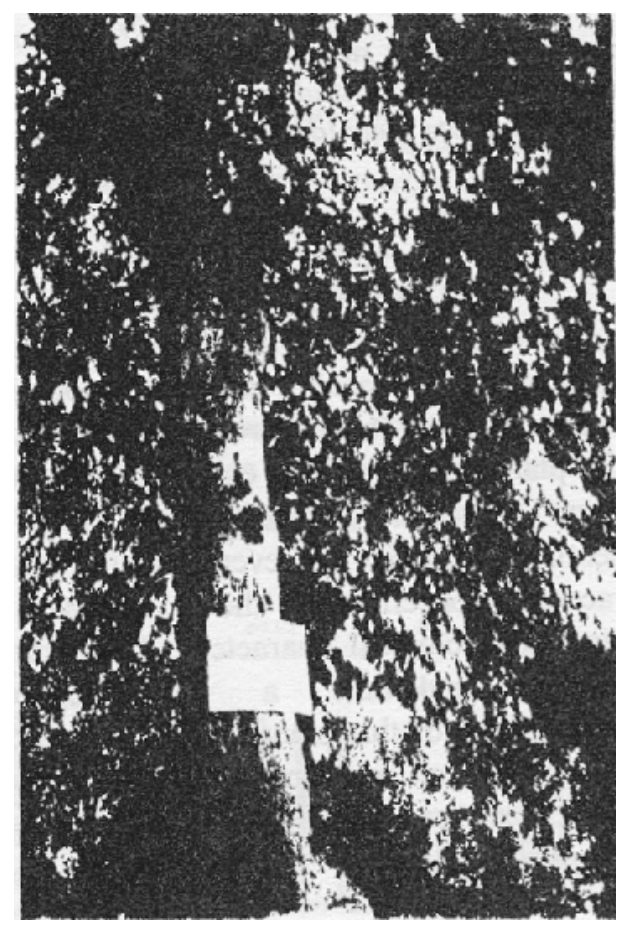

Fig. 1: Photograph of Flacourtia cataphracta Roxb (photo x 1/35)

\section{A- The Stem}

\section{Macromorphology of the stem}

The main trunk of the plant (Fig. 1) is erect, cylindrical, woody monopodially branched reaching 5-7 $\mathrm{m}$ in height and 15-20 $\mathrm{cm}$ in diameter. It carries numerous cylindrical alternate or opposite decussate branches with short internodes, The young branches (Fig. 2D) are spiny having green colour with smooth surface, while the older parts are light brown, rough and covered with brownish ridged cork, longitudinally wrinkled and carrying scars of fallen leaves. It is broken with fibrous fracture and has faint odour and slight bitter taste.

\section{Micromorphology of the young stem (Fig.} 3A)

A transverse section in the young stem is nearly circular in outline, showing an outer epidermis carrying few hairs followed by a cortex and a pericycle surrounding a continuous ring of vascular tissues with a wide parenchymatous pith in the center. The endodermis is indistinct.

The epidermis (Fig. 3B)

The epidermis of young stem is formed of one row of square to subrectangular cells in transverse section, while in surface view (Fig. 3C) is polygonal, square to subrectangular with straight, moderately thick anticlinal walls covered with smooth cuticle and measure (11.5-20-28.5) in length, (8.5-13-17) in width, (5.7-8.5-11.5) in height. They carry few non-glandular unicellular conical hairs with bent blunt apices, basal wide lumina, covered with smooth cuticle, measuring (5765-85) in length and (6-11.5-17) in width. No stomata are observed.

The cortex (Fig. 3B)

The cortex is formed of an outer zone of 2-3 rows of thick-walled collenchymatous cells, followed by a wider zone of rounded, oval-shaped parenchyma cells with thin walls and narrow intercellular spaces. Some of them contain prismatic crystals of calcium oxalate measure (8.5-14-20) in length and (5.7-7-8.5)

in width and cluster crystals measuring (8.514-20) in diameter.

\section{The pericycle (Fig. 3B)}

The pericycle is formed of a more or less continuous ring of fibers interrupted by few sclerenchmatous cells. The fibers have moderately thick, lignified irregular margin with comparatively narrow lumina and blunt to rounded apices, measuring (8-16-29) in diameter and (200-270-340) in length. Some of the parenchyma cells surrounding the fibers 


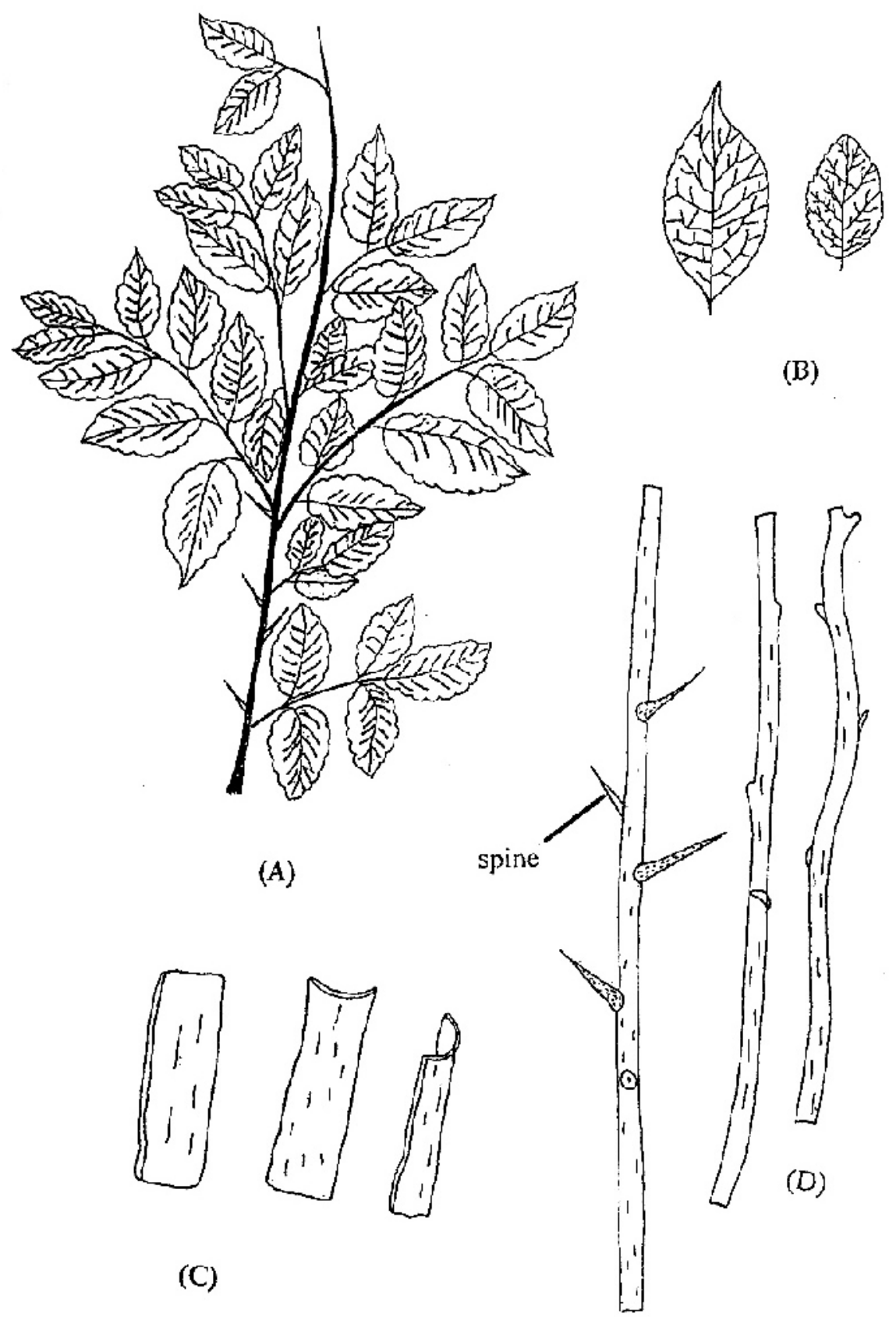

Fig. 2: Macromorphology of Leaf, Stem and Stem-Bark
A) Morphology of a Branch
$\left(\mathrm{X}^{1 / 4}\right)$
B) Morphology of the Leaf
$\left(\mathrm{x}^{1 / 2}\right)$
C) Morphology of the Stem-Bark
$\left(\mathrm{x}^{1 / 4}\right)$
D) Morphology of the Stem
(x 0.7 ) 


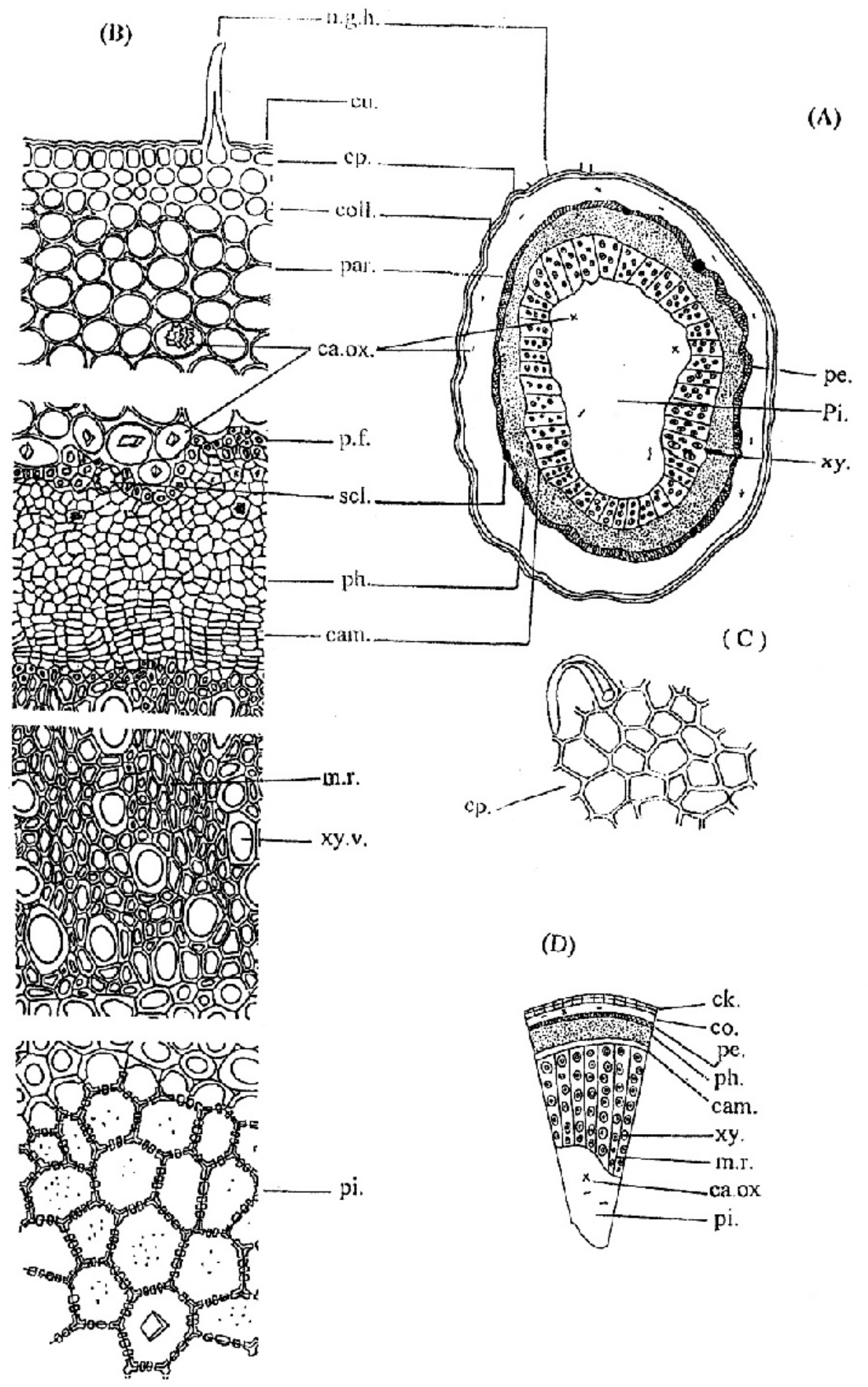

Fig. 3: Micromorphology of Stem

A) T.S. Diagram of the Young Stem

B) Detailed T.S. Sector of the Young Stem

C) Surface Preparation of the Young Stem

D) T.S. Diagram of the Moderately Aged Stem

(x 17.5)

cam., cambium; ca.ox., calcium oxalate; co., cortex; coll., collenchyma; ck., cork; cu., cuticle; ep., epidermis; m.r., medullary ray; n.g.h., non-glandular hair; par., parenchyma; pe., pericycle; p.f., pericyclic fibers; ph., phloem; pi., pith; scl., sclerenchymatous cells; xy., xylem; xy.v., xylem vessels. 
contain prisms of calcium oxalate forming a crystal sheath. The sclerenchymatous cells are few polygonal, nearly isodiametric to round with thick lignified walls, comparatively wide lumina and measuring (32-51-69) in length and (17-23-29) in width.

\section{The vascular system (Fig. 3B)}

It is represented by a continuous ring of phloem, cambium and xylem. The phloem is formed of sieve tubes, companion cells and phloem parenchyma containing small cluster crystals of calcium oxalate; measuring (3-4-5)

in diameter. The phloem is separated from the xylem by cambial zone, formed of few rows of thin-walled subrectangular tangentially elongated and radially arranged cellulosic cells free of contents.

The xylem is formed of lignified radiallyarranged elements. The vessels are lignified with reticulate and spiral thickening; measuring (17-28-40) in diameter. The wood parenchyma cells are subrectangular with lignified pitted walls and measure (23-35-46) in length and (8.5-13-17) in width. The tracheids have blunt ends and show lignified pitted thickening (Fig. 4), they measure (60-95130) in length and (11.5-15-20) in width. Wood fibers are abundant, elongated with blunt to rounded apices, narrow lumina and lignified straight or slightly irregular walls and measure (200-243-286) in length, (9-10-11) in diameter. The medullary rays are uni- to triseriate in the xylem region, consisting of radially elongated subrectangular cells with thick pitted and lignified walls, while being soft and cellulosic in the phloem region.

The pith (Fig. 3B) is formed of a wide central zone of rounded to oval parenchmatous cells, the outer three rows are formed of thickwalled cellulosic cells and the rest having thick finely pitted and slightly lignified walls. The size of the cells increases towards the center, they contain few prismatic crystals of calcium oxalate measuring (10-12.5-15) in length and (8-9-10) in width.

\section{Micromorphology of the moderate-aged stem (Fig. 3D)}

A transverse section in the moderate-aged stem is nearly circular in outline with an outer cork. The phellogen originates superficially in the subepidermal region. The cork is followed by a moderately narrow secondary cortex, a narrow collapsed remaining of the primary cortex, then a continuous zone of pericycle which surrounds the vascular cylinder. The vascular system is formed of a complete ring of secondary elements enclosing a comparatively narrow pith.

\section{The powdered stem (Fig. 4)}

The powdered stem is yellowish green in colour with faint odour and bitter taste.It is characterized microscopically by the presence of the following fragments:

1- Fragments of polygonal, square to subrectangular epidermal cells with straight anticlinal walls and covered with smooth cuticle. Stomata are almost absent, while few nonglandular unicellular conical hairs are observed.

2- Fragments of rounded to oval thin-walled parenchymatous cells of the cortex containing prismatic and cluster crystals of calcium oxalate.

3- Fragments of lignified pericyclic fibers with irregular margin, comparatively wide lumina with blunt to rounded apices. They are surrounded by parenchymatous cells containing prisms of calcium oxalate forming a crystal sheath.

4- Numerous prisms and cluster crystals of calcium oxalate.

5- Fragments of subrectangular lignified pitted wood parenchyma.

6- Fragments of large, polygonal, thickwalled, slightly lignified and pitted parenchymatous cells from the pith containing few prisms of calcium oxalate.

7- Fragments of lignified reticulate and spiral xylem vessels.

8- Fragments of wood fibers, which are elongated with, acute to rounded apices and showing comparatively narrow lumina.

9- Fragments of subrectangular elongated tracheids with pitted lignified walls.

10- Few isodiametric to subrectangular sclerenchymatous cells having thick lignified walls and narrow to wide lumina.

11- Fragments of subrectangular lignified medullary ray cells.

12- Few fragments of polygonal, isodiammetric slightly elongated nonlignified cells from the cork of the moderately-aged stem. 

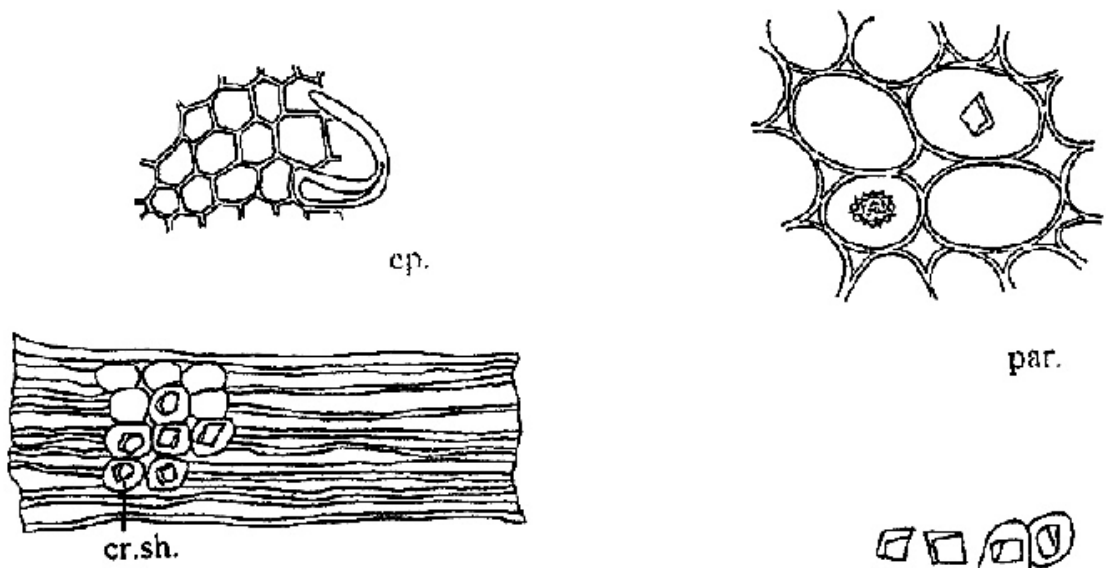

par.
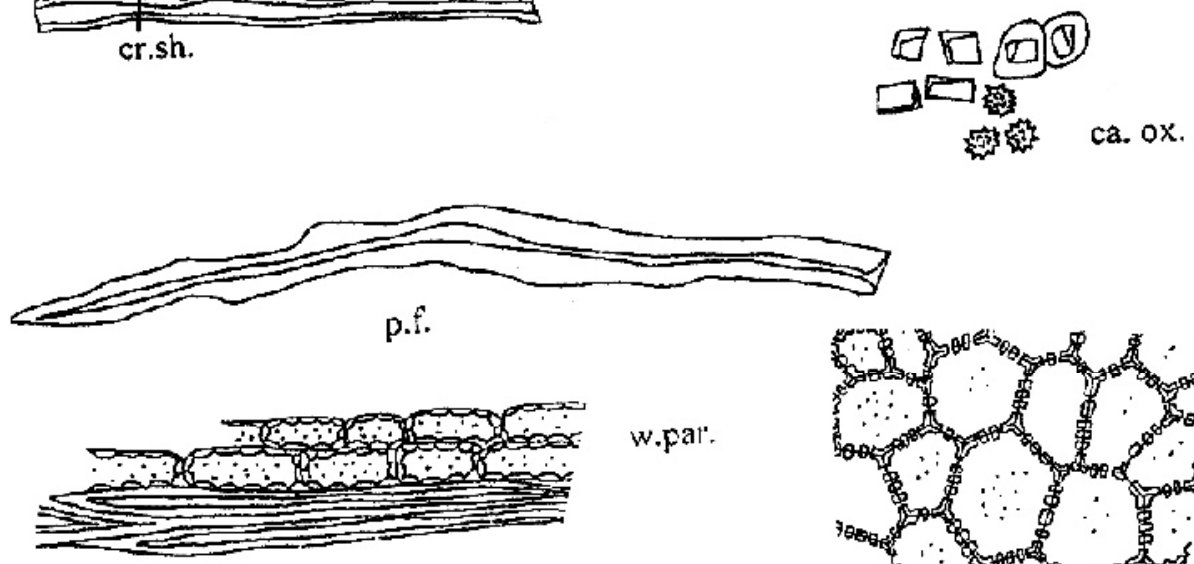

w.par:

w.f.
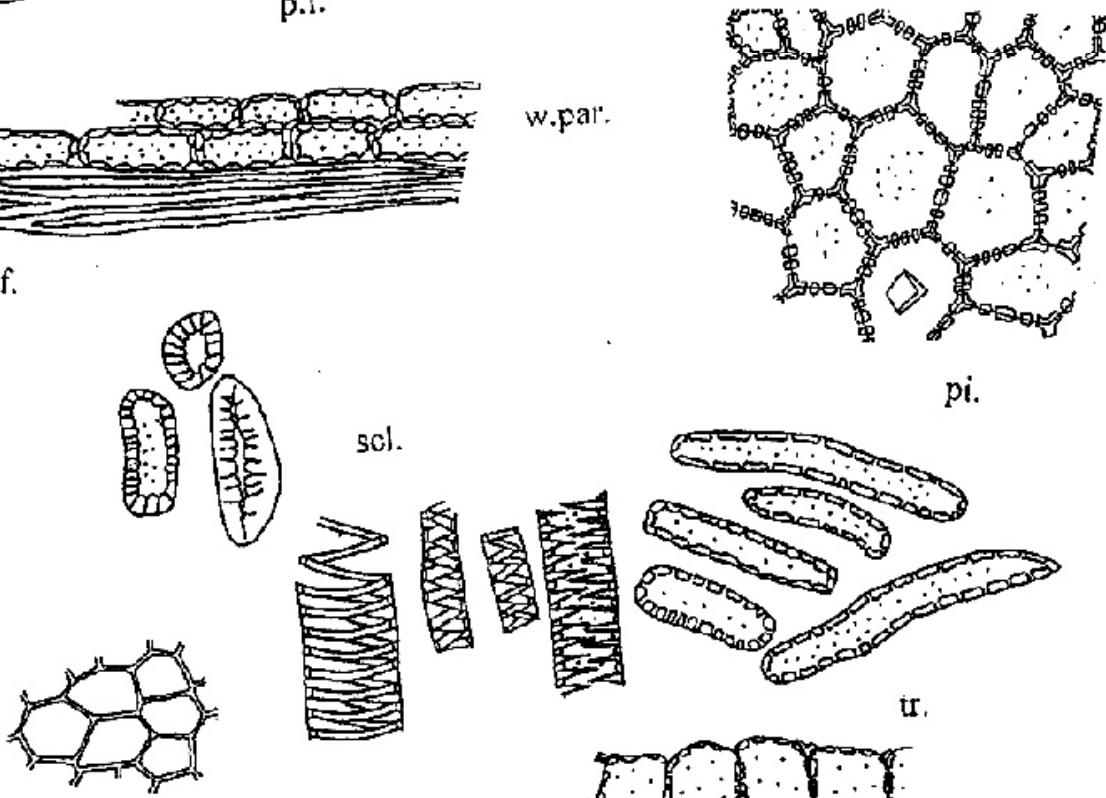

pi.

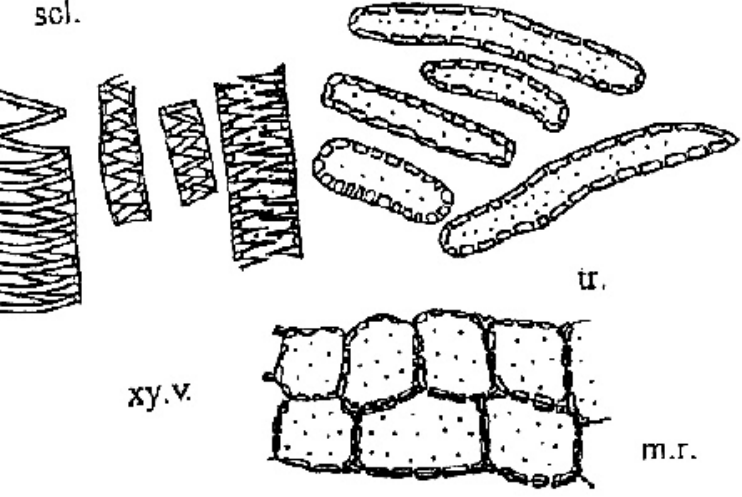

Fig. 4: Diagnostic Elements of Powdered Stem

ca.ox., calcium oxalate; ck., cork; cr.sh., crystal sheath; ep., epidermis; m.r. medullary ray; par., parenchyma; p.f., pericyclic fibers; pi., pith; scl., sclerenchymatous cells; tr., tracheids; w.f., wood fibres; w.par., wood parenchyma; xy.v., xylem vessels. 


\section{B- The Leaf}

\section{Macromorphology of the leaf}

The leaf is simple, petiolate, exstipulate (Fig. 2A\&B), varying in shape and size, being ovate, obovate to ovate-acuminate, alternate or spirally arranged, in the terminal young branch a spine arises from the axil of the leaf; measuring, $1.5-2 \mathrm{~cm}$ in length. The leaf has a serrate margin, symmetric base and acute to acuminate apices, pinnate-reticulate venation. The midrib and lateral veins are more prominent on the lower surface. The upper surface is dark green in colour, while the lower surface being paler; the texture is glossy on both surfaces. The leaf measures, $5-10 \mathrm{~cm}$ in length and $1.25-5 \mathrm{~cm}$ in width. Petiole is cylindrical to subcylinderical, green in colour, short, measuring 3-6 $\mathrm{mm}$ in length and 2-3 $\mathrm{mm}$ in diameter, the leaf has faint odour and bitter taste.

\section{Micromorphology of the leaf}

A transverse section in the lamina of the leaf through the midrib (Fig. 5A) appears more or less slightly biconvex in outline. It consists of upper and lower epidermises, the upper epidermis only carries few non-glandular unicellular hairs. The epidermises enclose in between an isobilateral mesophyll, interrupted in the midrib region by collenchyma. The vascular system in the midrib region is represented by a large crescent-shaped main vascular bundle surrounded by an incomplete ring of pericyclic fibers. The mesophyll contains scattered prisms and cluster crystals of calcium oxalate.

\section{The upper epidermis (Fig. 6A)}

The upper epidermis appears as one row of isodiametric to subrectangular thin-walled cellulosic cells, while in surfe view (Fig. 5C), they are polygonal, subrectangular, rarely isodiametric, axially elongated with wavy anticlinal walls and covered with smooth cuticle. The cells measure about, (24-28-35) in length, (6.5-12.5-19) in width and (8-1012) in height. They carry nonglandular unicellular hairs, which are nearly conical in shape with tapering bent apices and basal wide lumina. They are covered with thick smooth cuticle and measure (64- $\underline{-64-104)}$ in length and (5-7.5-10) in width. Stomata are almost absent.
The lower epidermis (Fig. 6B)

The lower epidermis in transverse section appears as one row of isodiametric to subrectangular thin-walled cellulosic cells. In surface view (Fig. 5B) they are polygonal, axially elongated cells with wavy anticlinal walls, covered with smooth cuticle and measure (19-25-32) in length, (6.5-8-10) in width and (9.5-10-13) in height.The stomata are abundant, they are rounded to oval in shape and of paracytic type, surrounded mostly by 2 rarely 3 cells and measure (14.5-11-18) in diameter, hairs are almost absent.

Both the upper and lower neural epidermal cells are nearly similar in surface view (Fig. 5D) being polygonal, square to subrectangular in shape with straight anticlinal walls, covered with smooth cuticle and measure (14-24-34) in length and (11.5-14-17) in width.

\section{The mesophyll (Fig. 6C)}

The upper palisade consists of two rows of columnar, cylindrical cells, with straight to slightly wavy walls containing chloroplasts and measure (17-25-23) in length and (8.5-11-14)

in width. The lower palisade is represented by one row of nearly square to rounded parenchymatous cells containing chloroplasts. The spongy tissue consist of 3-5 rows of thinwalled small rounded parenchymatous cells with moderately narrow intercellular spaces, some cells contain chloroplasts and the others contain cluster and prisms of calcium oxalate measuring (12-15-18) in diameter, (4- $\underline{-5}-6)$ in length and (3- $-4-5)$ in width; respectively.

\section{The cortical tissue (Fig. 6A)}

The cortical tissue in the midrib region is represented by upper and lower subepidermal zones, each consisting of 2-3 rows of thickwalled cellulosic collenchyma cells, followed by few rows of oval to rounded thin-walled cellulosic parenchyma cells with moderately wide intercellular spaces.

\section{The vascular system (Fig. 6A)}

It is represented by several collateral vascular bundles of variable size scattered in the lamina and a large one being situated in the midrib region. Each vascular bundle is formed of a radiating upper xylem and a lower phloem region, surrounded by an incomplete ring of pericyclic fibers. 

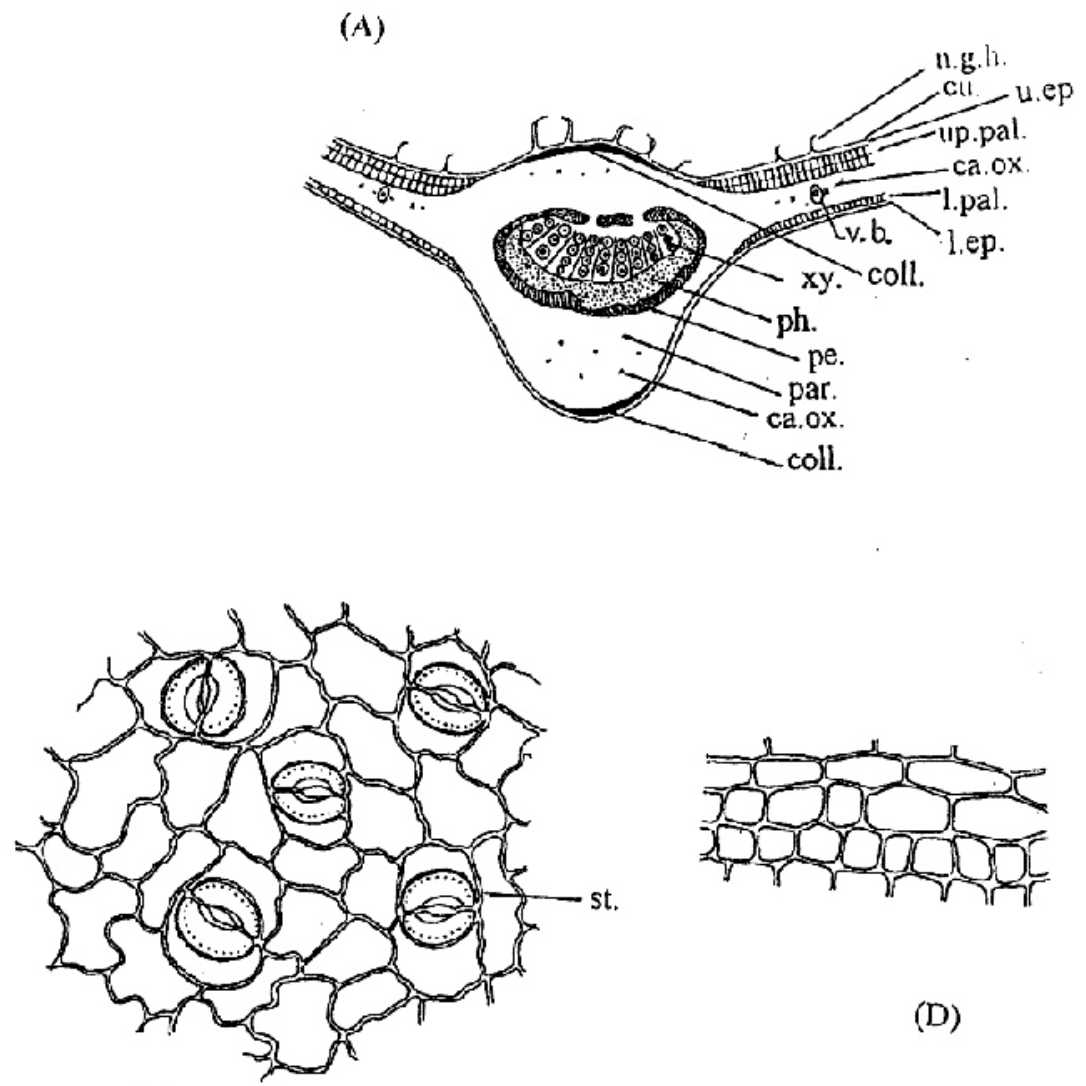

(B)

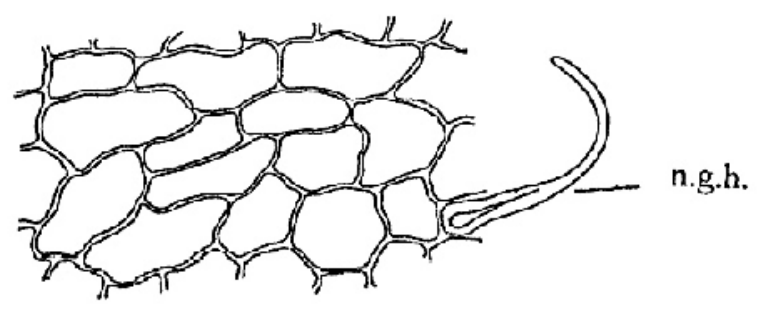

(C)

Fig. 5: Micromorphology of the Leaf

A) T.S. Diagram of the Leaf

B) Surface Preparation of Lower Epidermis

C) Surface Preparation of Upper Epidermis

D) Surface Preparation of Neural Epidermal Cells

ca.ox., calcium oxalate; coll., collenchyma; cu., cuticle; 1.ep., lower epidermis; 1.pal., lower palisade; n.g.h., non-glandular hair; par., parenchyma; pe., pericycle; ph., phloem; st., stomata; u.pal., upper palisade; u.ep., upper epidermis; v.b., vascular bundle; xy., xylem. 

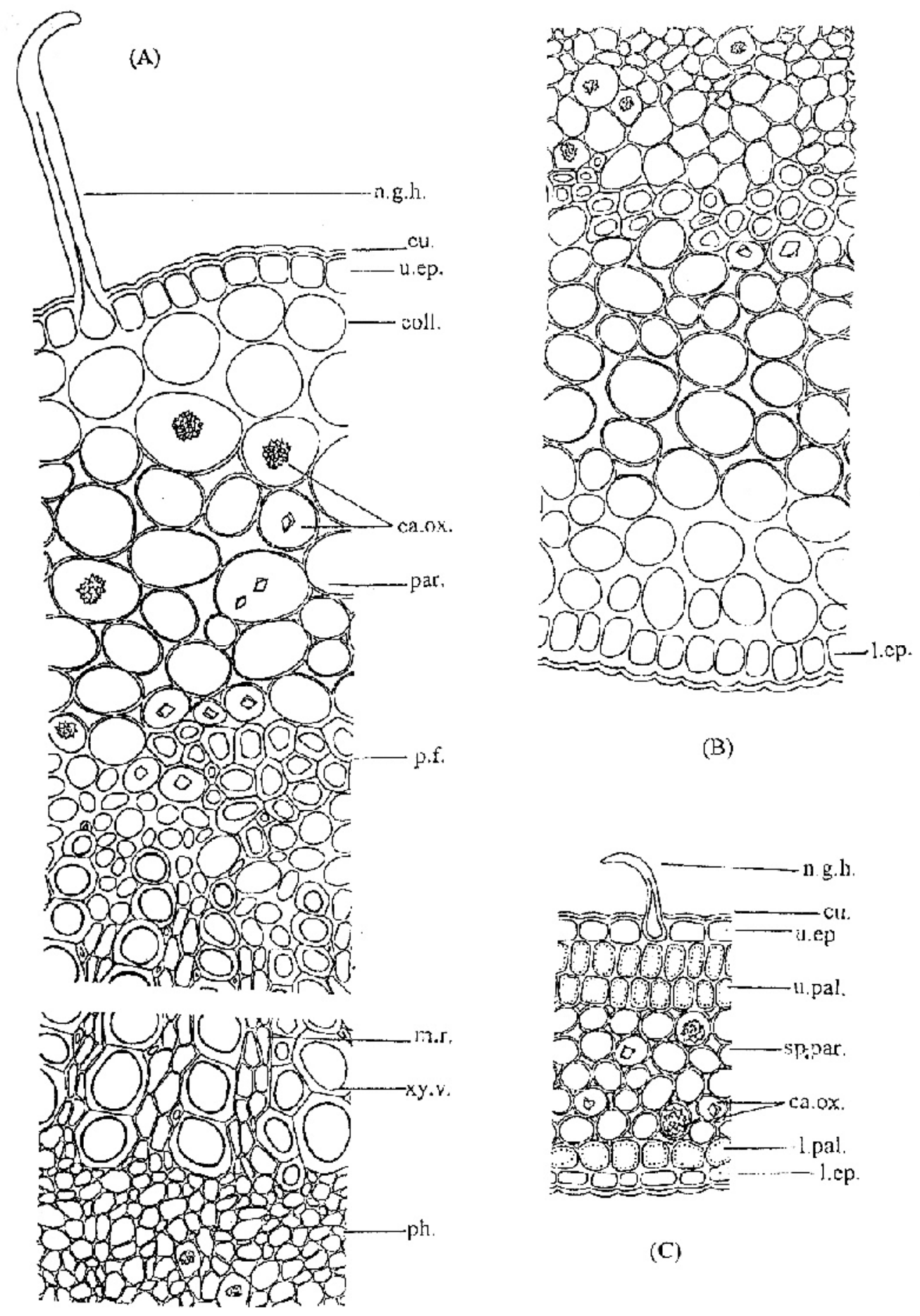

(B)

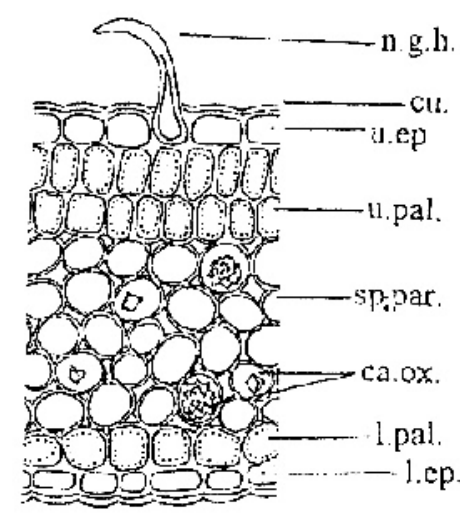

(C)

Fig. 6: Micromorphology of the Leaf

A\&B) Detailed T.S. Sector in the Leaf

C) Detailed T.S. Sector in the Lamina

ca.ox., calcium oxalate; coll., collenchyma; cu., cuticle; 1.ep., lower epidermis; 1.pal., lower palisade; m.r., medullary ray; n.g.h., non-glandular hair; par., parenchyma; p.f., pericyclic fiber; ph., phloem; sp.par., spongy parenchyma; u.pal., upper palisade; u.ep., upper epidermis; xy.v., xylem vessels. 
The pericyclic fibers are lignified with moderately wide lumina, irregular margin, acute to rounded apices and measure (257-385514) in length and (6-17-28) in diameter.

Some of the cortical parenchyma, especially those surrounding the pericyclic fibers, contain prisms of calcium oxalate forming a crystal sheath.

\section{The xylem (Fig. 6A)}

The xylem is formed of lignified spiral and reticulate vessels, wood fibers and wood parenchyma where the xylem vessels measure (10-20-30) in diameter. The xylem vessels are traversed by uni- to biseriate rectangular cellulosic medullary ray cells. The wood fibers are few with lignified walls, narrow lumina, rounded to acute apices and measure (228.5271-314) in length and (8.5-11-14) in diameter.

\section{The phloem (Fig. 6A\&B)}

The phloem is formed of soft cellulosic elements below the xylem, it consists of sieve tubes, companion cells and phloem parenchyma, most of them contain small cluster crystals of calcium oxalate measuring (6- $\underline{-1}-8)$ in diameter.

\section{The petiole (Fig. 7A)}

A transverse section in the petiole is nearly triangular in shape with rounded angles. It has an outer epidermis carrying few hairs followed by a wide parenchymatous cortex enclosing a central vascular system.

\section{The epidermis (Fig. 7B)}

The epidermis in transverse section consists of one row of isodiametric to subrectangular cells. In surface view (Fig. 7C), the epidermal cells are polygonal, nearly isodiametric sometimes subrectangular with thin straight anticlinal walls, covered with smooth cuticle and measure (12-15-28) in length, (8.5-12-15) in width and (10-13-16) in height. They carry few nonglandular unicellular conical hairs covered with smooth cuticle, with bent blunt apices and having wide lumina at the base, they measure (60- $\underline{80-100)}$ in length and (10-15-20) in width. Stomata are almost absent.
The cortical tissue (Fig. 7B)

The cortex consists of several rows of rounded to oval parenchymatous cells with wide intercellular spaces and containing cluster crystals of calcium oxalate measuring (12-1620) in diameter in addition to prismatic crystals measuring (4-5-6) in length and (3- -4 5) in width.

\section{The vascular system (Fig. 7B)}

The vascular system is represented by one main crescent-shaped vascular bundle consisting of an upper xylem followed by a lower arc of phloem and surrounded by a lower arc of pericyclic fibers. The pericycle is formed of groups of lignified fibers with straight walls, moderately narrow lumina, acute to rounded apices and measure (170-250-330) in length and (8-17-26) in diameter. The xylem consists of lignified spiral and reticulate vessels measuring (16-23-30) in diameter. The wood parenchyma is formed of polygonal subrectangular cells having thick-walled lignified cells. The medullary rays are uni- to biseriate, polygonal to subrectangular, thickwalled cellulosic cells. The phloem consists of several rows of small thin-walled soft elements which consist of sieve tubes, companion cells and phloem parenchyma containing small cluster crystals of calcium oxalate measuring (4-5-6) in diameter.

\section{The powdered leaf (Fig. 8)}

The powdered leaf is dark green in colour with faint odour and bitter taste. It is characterized microscopically by the following fragments:

1- Fragments of both upper and lower epidermises which are polygonal to somewhat elongated cells with wavy anticlinal walls, covered with smooth cuticle. The upper epidermis only carry nonglandular conical unicellular hairs covered with thick smooth cuticle and have tapering bent apices, while the lower epidermis only shows rounded to oval paracytic stomata.

2- Fragments of the mesophyll showing columnar palisade cells with chloroplasts and parenchyma cells containing cluster and prismatic crystals of calcium oxalate. 
(B)
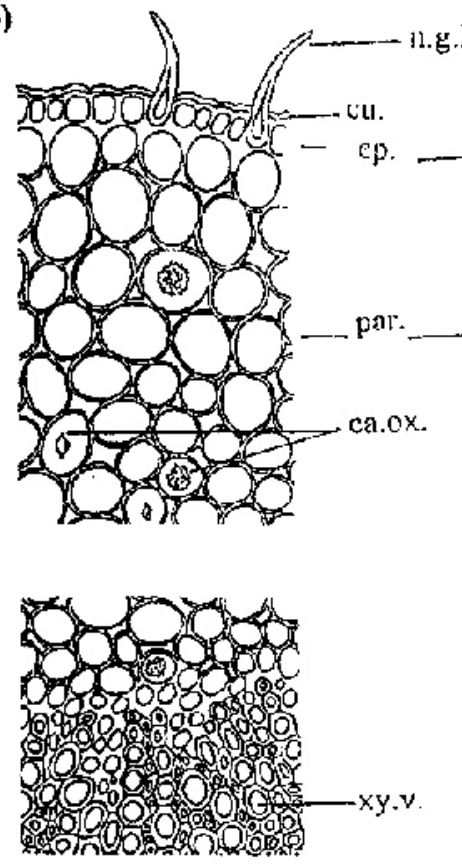

(A)

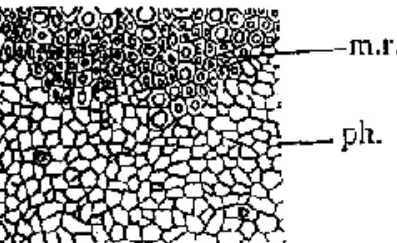

(C)
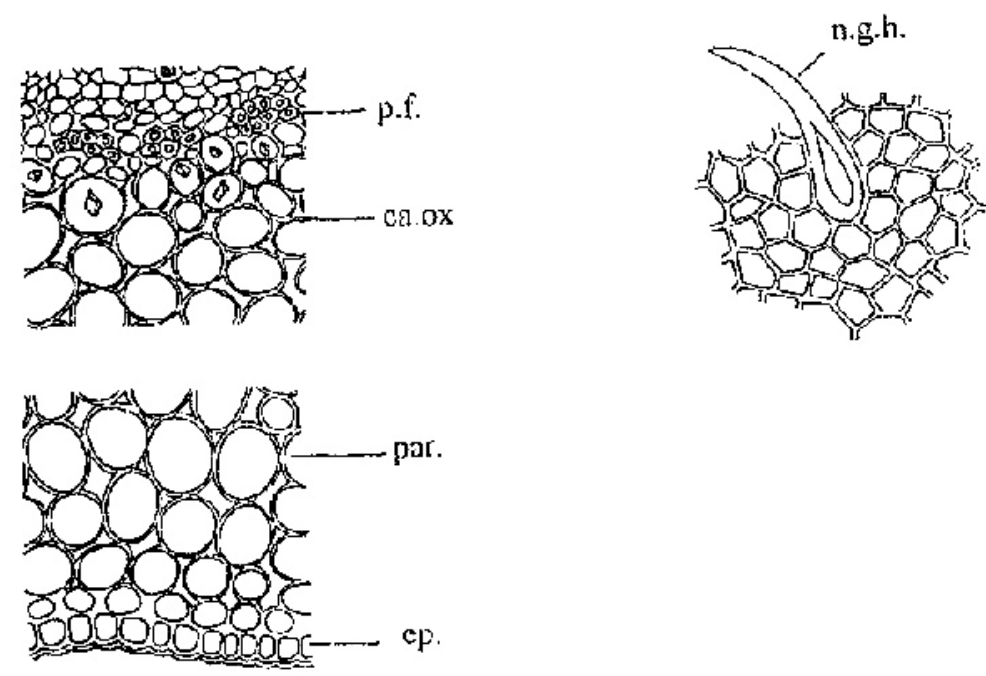

Fig. 7: Micromorphology of the Leaf: The Petiole
A) T.S. Diagram of the Petiole
B) Detailed T.S. Sector of the Petiole
C) Surface Preparation of the Petiole

ca.ox., calcium oxalate; cu., cuticle; ep., epidermis; m.r., medullry ray; n.g.h., non-glandular hair; par., parenchyma; pe., pericycle; p.f., pericyclic fiber; ph., phloem; xy., xylem; xy.v., xylem vessels. 

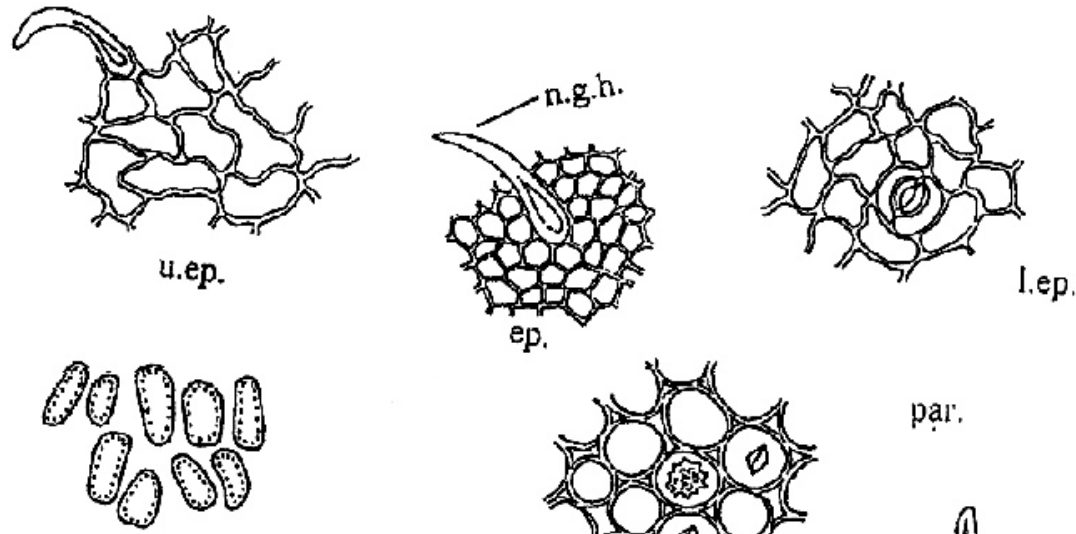

pal.

ep.

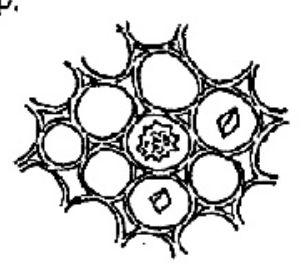

pạl:

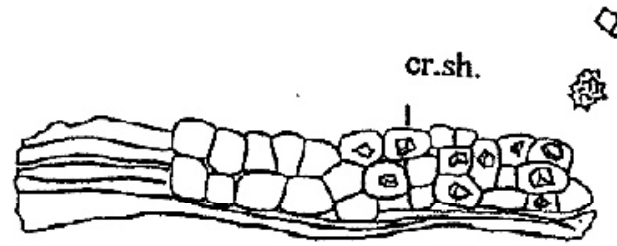

80 䠉 通
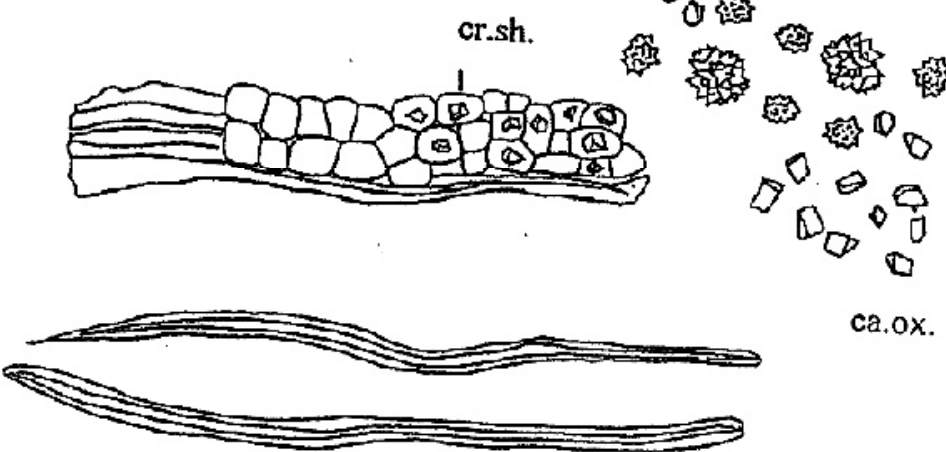

ca.ox.

w. . .

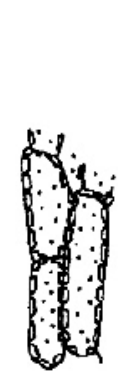

w.par.

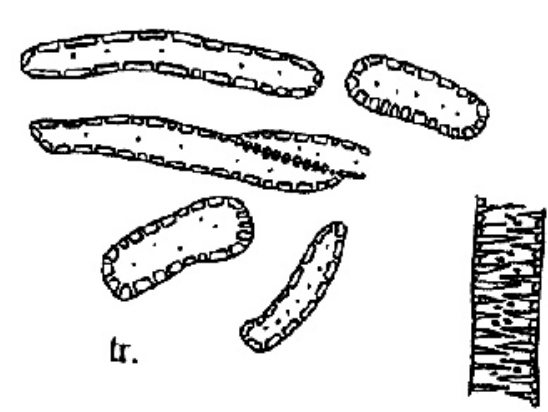

Fig. 8: Diagnostic Elements of Powdered Leaf

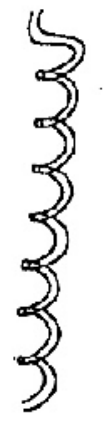

$x y . v$

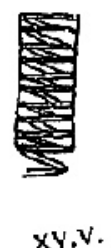

(x 245)

ca.ox., calcium oxalate; cr.sh., crystal sheath; ep., epidermis; l.ep., lower epidermis; n.g.h., non-glandular hair; pal., palisade; par., parenchyma; p.f. pericyclic fibers; tr., tracheids; u.ep., upper epidermis; w.f., wood fibers; w.par., wood parenchyma; xy.v., xylem vessels. 
3- Abundant entire or broken pericyclic fibers with moderately-thickened lignified walls and moderately wide lumina, irregular margin and acute to rounded apices, some of them are surrounded by parenchyma containing prisms of calcium oxalate forming a crystal sheath.

4- Abundant clusters of calcium oxalate of variable size in addition to prismatic crystals.

5- Fragments of wood fibers with lignified walls, moderately narrow lumina and rounded to acute apices.

6- Fragments of lignified xylem vessels showing spiral and reticulate thickening.

7- Fragments of polygonal, isodiametric wood parenchyma cells with slightly lignified walls.

8- Fragments of subrectangular tracheids with lignified-pitted walls.

9- Fragments of polygonal, nearly isodiametric cells with straight anticlinal walls, carrying conical unicellular nonglandular hairs from the epidermis of the petiole.

\section{Macromorphology of the stem-bark}

The stem-bark (Fig. 2C) consists of flat to slightly curved pieces, measuring $(6-12 \mathrm{~cm})$ in length, $(3-5 \mathrm{~cm})$ in width and $3 \mathrm{~mm}$ in thickness. The outer surface is covered with, rough and dark-brown cork; while the inner surface is finely longitudinally striated and brownish in colour. The fracture is short and the stem-bark has faint odour and bitter taste.

\section{Micromorphology of the stem-bark}

A transverse section in the stem bark (Fig. 9A) shows three distinct regions: the cork, the cortex and the phloem region. The cork consists of several rows of radially elongated cells. The cortex is comparatively narrow, formed of outer 3-4 rows of collenchymatous cells followed by thin-walled irregular shaped parenchyma cells containing prisms of calcium oxalate. The innermost layer of the cortex shows few groups of lignified pericyclic fibers associated with sclerenchymatous cells forming the pericyclic region. The phloem appears as a wide zone traversed by uni- to triseriate medullary rays.

\section{The cork (Fig. 9B)}

It is formed of several rows (up to 8 rows) of radially arranged tangentially elongated, tabular to subrectangular cells with thin nonlignified walls. The outer rows of the cork contain yellowish brown contents, while the rest being free of contents. The cork cells in surface view (Fig. 10) are polygonal, isodiametric to slightly elongated with straight anticlinal walls; measuring (26-35-44) in length (17-23-28.5) in width and (8-14-20) in height. The phellogen consists of thin-walled tangentially elongated cells.

\section{The cortex (Fig. 9B)}

It consists of outer 3-4 rows of collenchymatous cells, followed by thinwalled, oval to elongated parenchyma cells. They contain few prisms of calcium oxalate measuring (10-25-40) in length and (10-1316) in width. Few sclerenchymatous cells are scattered in the outer cortical region. They are subrectangular to isodiametric in shape with thick, lignified walls and wide, sometimes, narrow lumina measuring (16-22-28) in length and (8-10-12) width.

The pericycle (Fig. 9B) consists of few groups of pericyclic fibers associated with sclerenchymatous cells. They have lignified thick, irregular walls, somewhat wide lumina with acute to acuminate apices, measuring (270-420-570) in length and (10-17-25) in diameter.

The sclerenchymatous cells are polygonal subrectangular to fusiform with thick-lignified pitted walls and measuring (15-30-46) in length and (8-14-20) in width. Some cells contain prisms of calcium oxalate. The parenchyma cells surrounding the fibers contain prisms of calcium oxalate forming a crystal sheath (Fig. 9C).

\section{The phloem (Fig. 9B)}

The phloem zone is comparatively wide, formed of few phloem fibers accompanied by sclerenchymatous cells. The phloem parenchyma are subrectangular, thick-walled, nonlignified and contain prisms of calcium oxalate. The sieve elements (sieve tubes and companion cells) are indistinguishable. The phloem fibers have thick lignified walls. Triseriate medullary rays, formed of elongated polygonal thick-walled lignified cells traverse the phloem parenchyma. 

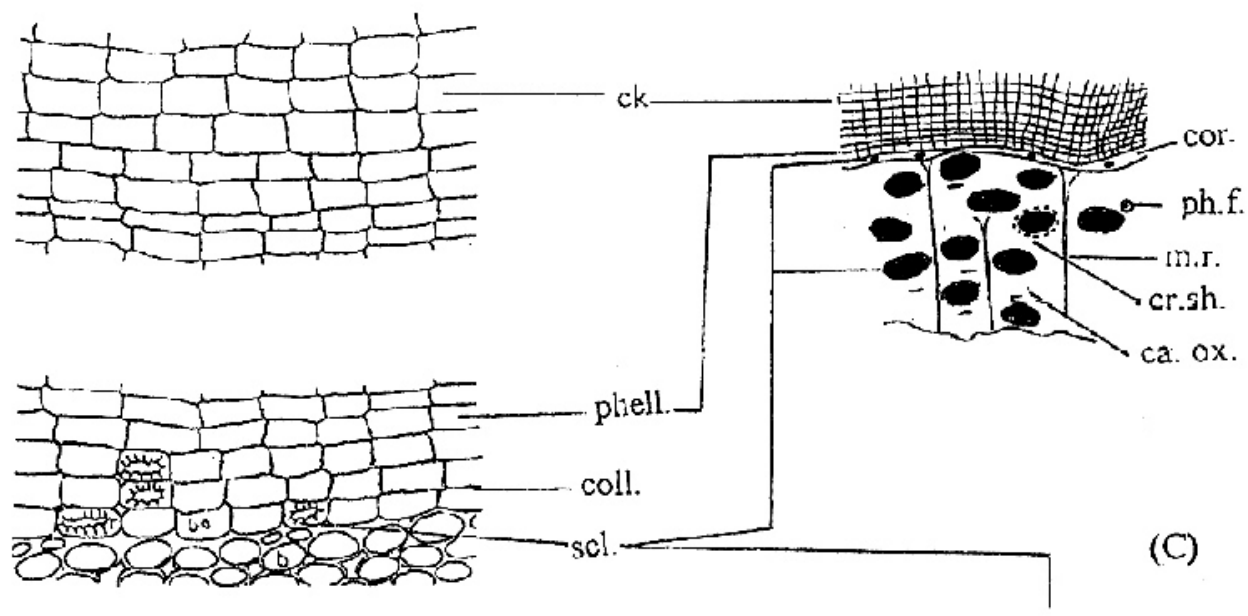

(C)

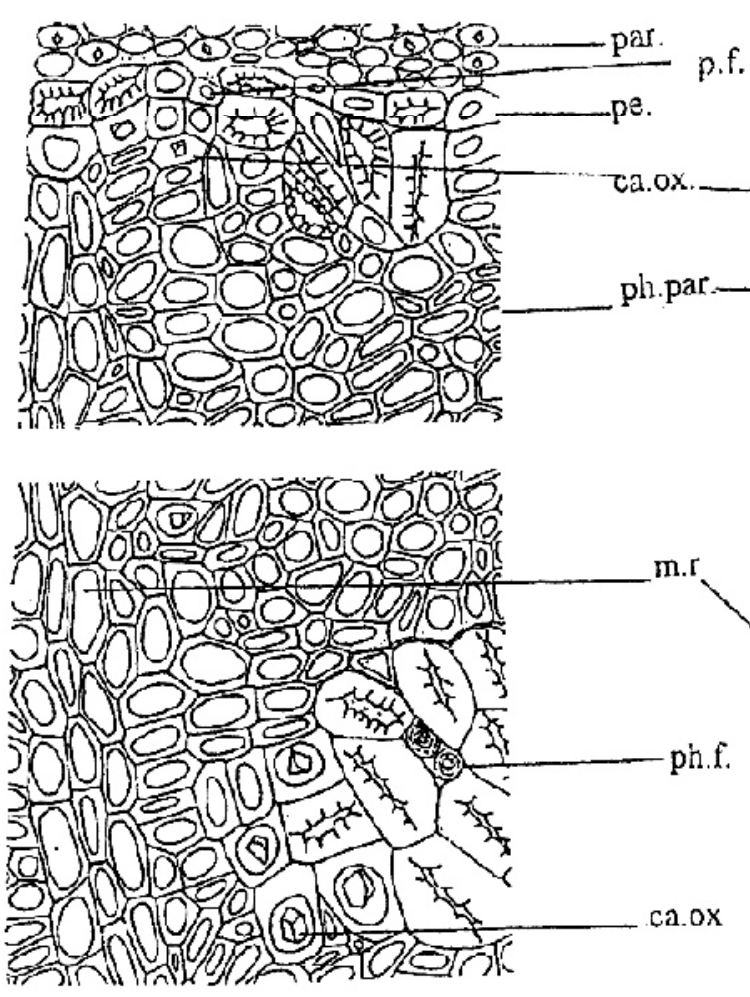

(x 35)

Fig. 9: Micromorphology of Stem-Bark
A) T.S. Diagram in the Stem-Bark
B) Detailed T.S. Sector in the Stem-Bark
C) Detailed L.S. Sector in the Stem-Bark

ca.ox, calcium oxalate; ck., cork; coll., collenchyma; cor., cortex; m.r., medullary ray; par., parenchyma; phell., phellogen; pe., pericycle; p.f., pericyclic fiber; ph.f., phloem fiber; ph.par., phloem parenchyma; scl., sclerenchymatous cells; cr.sh., crystal sheath. 


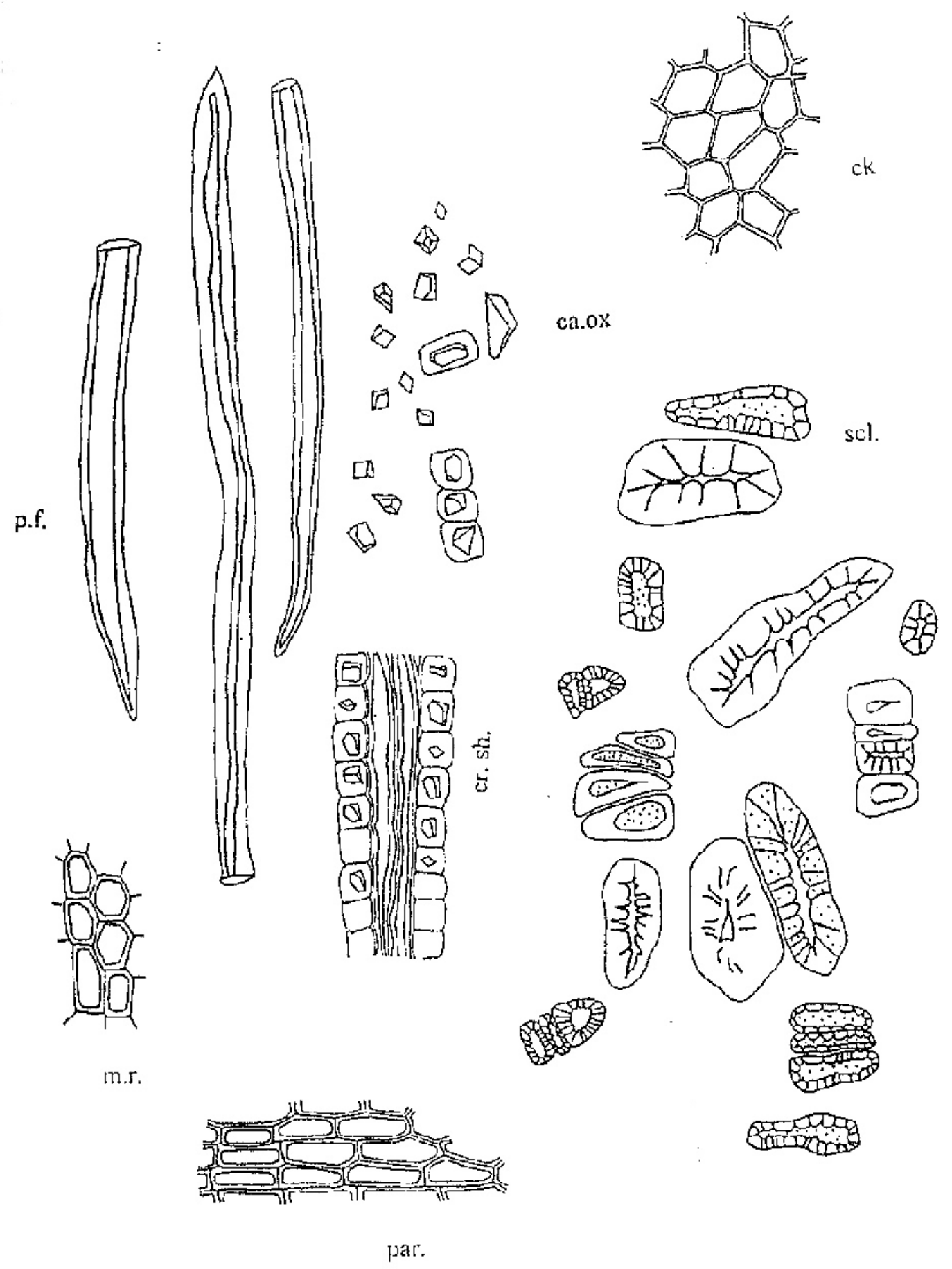

Fig. 10: Diagnostic Elements of Powdered Stem-Bark

(x 245)

ca.ox., calcium oxalate; ck., cork; cr.sh., crstal sheath; m.r., medullary ray; par., parenchyma; p.f., pericyclic fiber; scl., sclerenchymatous cells. 
Powdered stem-bark (Fig. 10)

The powdered stem-bark is yellowishbrown in colour with faint odour and bitter taste. It is characterized microscopically by the following fragments:

1- Fragments of polygonal, nearly isodiametric, thin-walled, nonlignified cork cells with yellowish-brown contents.

2- Fragments of lignified pericyclic fibers with irregular thick walls, wide lumina and acute to acuminate apices, either isolated or in association with parenchyma cells containing prisms of calcium oxalate forming a crystal sheath.

3- Few prisms of calcium oxalate.

4- Numerous sclerenchymatous cells either isolated or in groups being polygonal, isodiametric subrectangular to fusiform in shape with thick, pitted lignified walls and narrow or wide lumina.

5- Fragments of subrectangular thick-walled, nonlignified phloem parenchyma cells containing prisms of calcium oxalate.

6- Fragments of subrectangular, lignified cells representing the medullary rays.

\section{REFERENCES}

1- J. C. Wills, A Dictionary of the Flowering Plants and Ferns, Cambridge University Press, 1973, pp. 461-462.

2- C. B. Cronk, Quentin and J. L. Fuller, Plant Invaders, Chappman and Hall., 1995, p. 241.

3- W. R. Sykes, New Zealand Department of Scientific and Industrial Research Bulletin, 200, 96-98 (1970).

4- L. M. Parry and J. Metzger, Medicinal Plants of East and South Asia, The MIT Press, Cambridge, Massachuetts and London, England, 1980, pp. 154-156.

5- J. Morton, Kei Apple, In: Fruits of Warm Climates, Miami, Fl., 1987, pp. 315-319.

6- K. R. Kirtikar, B. D. Basu and L. T. Colonel, Indian Medicinal Plants, Prakash Publisher, Delhi, 1975, pp. 218-219.

7- A. C. Smith, Flora Vitiensis Nova: A New Flora of Fiji. Lawai, Kauai, Hawaii. National Tropical Botanical Garden, Vol. 2, 1981, p. 639.

8- J. Ahmed, K. Wizarat, K. M. Shamsuddin, A. Zaman and J. D. Connolly, Phytochemistry, 23 (6), 1269-1270 (1984).

9- K. S. Mukherjee, G. Brahmachari and T. K. Manna, J. Indian Chem. Soc., 74 (9), 738-739 (1997). 